\title{
The Effects of Western Diet on Sperm Quantity and Quality and Serum Hormonal Concentration in Cynomologus Monkey (Macaca fascicularis) Injected with Testosterone Enanthate (TE) plus Depot Medroxy Progesterone Acetate (DMPA) ${ }^{+)}$
}

\author{
Sutyarso*, N. Suhana**, N. Moeloek**, O. Soeradi**, S. Sri Sukmaniah***, J Supriatna****
}

\begin{abstract}
Abstrak
Tujuan penelitian ini ialah untuk mengetahui pengaruh diit negara barat atau Eropa terhadap jumlah dan kualitas spermatozoa dan konsentrasi hormon dalam serum pada sekelompok monyet (Macaca fascicularis) yang diinjeksi dengan kombinasi testosteron enantal (TE) dan depotmedroxy progesteron asetat(DMPA). Dua puluh monyet jantan dibagi menjadi dua kelompok tiap kelompok 10 ekor; kelompok pertama (I) diberi makan standar "monkey chow" yang susunannnya adalah: 9\% lemak, 13\% protein dan $78 \%$ karbohidrat, sedang kelompok kedua (II) diberi makanan diit model negara barat yang susunannya adalah: $35 \%$ lemak, 25\% protein dan 40\% karbohidrat. Tiga bulan setelah masa adaptasi kedua kelompok kera tersebut diinjeksi dengan $20 \mathrm{mg}$ TE dan $25 \mathrm{mg}$ DMPA dimulai pada minggu ke 0 sampai minggu ke 18, sedangkan TE dilanjutkan sampai minggu ke 24. Plasma semen dikumpulkan dengan menggunakan teknik elektro ejakulasi yang dilakukan tiap 3 minggu, jumlah dan kualitas spermatozoa ditetapkan berdasarkan metode WHO. Pengambilan darah untuk pemeriksaan hormon dilakukan tiap 6 minggu sekali. Pada kelompok I terjadi azoospermia 100\%, sedangkan pada kelompok II hanya mencapai $70 \%$ azoospermia. Pada kelompok I spermatozoa mulai ditemukan kembali pada minggu ke 33, tetapi sampai akhir penelitian (minggu ke 39) hanya mencapai ke keadaan oligospermia berat, bahkan dua individu tetap azoospermia. Pada kelompok II meningkatnya konsentrasi spermatozoa juga dimulai pada minggu ke 33 dan mencapai keadaan normospermia pada akhir penelitian (minggu ke 39). Pada kelompok I penurunan kualitas spermatozoa lebih besar daripada klelompk II. Kadar hormon menurun pada kelompok I lebih cepat daripada kelompok II, sedangkan pemulihannya lebih lambat dari pada kelompok II. Dari hasil penelitian tersebut dapat disimpulkan bahwa, perbedaan nutrisi dapat menyebabkan perbedaan terjadinya penurunan jumlah dan kualitas spermatozoa maupun penurunan hormon, pada M. fascicularis yang diinjeksi dengan TE dan Dsebut lebih cepat dan lebih besar pada kelompok I daripada pada kelompok II.
\end{abstract}

\begin{abstract}
The aim of this study is to elucidate the effects of western diet on sperm quantity and quality and serum hormone in cynomologus monkeys (Macaca fascicularis) injected with testosterone enanthate (TE) plus depotmedroxy progesterone acetate (DMPA). The twenty male monkeys are divided into two groups ten animals each. The Group (I) was fed with the "monkey chow" (9\% fat, $13 \%$ protein and $78 \%$ carbohydrate); the second group (II) was fed with "western" diet ( $35 \%$ fat, $25 \%$ protein and $40 \%$ carbohydrate) Three months after adaptation period, both groups were injected with $20 \mathrm{mg}$ TE and $25 \mathrm{mg}$ DMPA for 18 weeks, while TE injections continued for another 6 week. The semen for examination of Sperm density and quality using electro-ejaculation was done once every three weeks. and determined by WHO methods. The blood serum for hormone assay was taken once every six weeks. In group I azoospermia reached $100 \%$, while in the group II reached only $70 \%$. In both groups the spermatozoal count were recovered at week 33, but until this investigation terminated on week 39 the level of spermatozoa of group I reached only severe oligozoospermia, and two animals remained severe azoospermic; while group II has returned to normospermia. The quality of sperm during and after treatment in group II was better than group I. Hormone concentration decreased more rapidly in group I than in group II, while the recovery period was slower in group I compared to group II. This investigation concluded that different diet formula caused different results in decreasing the level of sperm quantity and quality, and hormone concentration of M.fascicularis injected with TE in combination with DMPA, being lower in animals fed with monkey chow diet than in animals fed with western diet.
\end{abstract}

Keywords: Contraception, Testosterone Enanthate \& Depot Medroxy Progesterone Acetate, Sperm quality \& quantity, Hormonal level, Macaca fascicularis.

+) Supported by The Project of Research Team "URGE" No: 023/ HTPP/URGE/1995. Department of Education \& Culture, Directorate General of Higher Education.

*) Department of Biology, Faculty of Mathematics \& Natural Science, University of Lampung/Biomedical Post Graduate Program, University of Indonesia, Jakarta, Indonesia
**) Department of Biology, Faculty of Medicine, University of Indonesia, Jakarta, Indonesia

***) Department of Nutrition, Faculty of Medicine, University of Indonesia, Jakarta, Indonesia

****) Department of Biology, Faculty of Mathematics \& Natural Science, University of Indonesia, Jakarta, Indonesia 


\section{INTRODUCTION}

There are differences in the efectiveness of injectable testosterone enanthate (TE) or in combination with depotmedroxy progesterone acetate (DMPA) on achieving azoospermic state between Indonesian, Chinese, and Caucasian. The injection of these hormones in Indonesian men achieved azoospermia of almost $100 \%,{ }^{1,2}$ in Chinese (injected by TE only ) over $90 \%,{ }^{3}$ whereas in Caucasian less than $70 \% .{ }^{4}$ This strongly suggests that Indonesian men exhibit a higher susceptibility to steroidal-induced suppression of spermatogenesis compared to Caucasian men, when the same doses of steroids were administered. Potential explanations for the greater susceptibility to steroid-induced azoospermia include populationbased (ethnic) differences in steroid metabolism, an insensitivity to steroidal suppression or differences in the kinetics of spermatogenesis. Such differences could in turn be due to physiological variations in genetic and environmental factors including nutrition or diet. ${ }^{1,2}$

Western diet is high in fat and protein, whereas Asian diet is low in fat and protein but high in carbohydrates. Nevertheless, the role of nutrien on reproductive function in men at the moment is still poorly understood. Nutritional status is also possible as a factor influencing steroid metabolism that affects fertility. Lermite and Terqui reported that nutritional status seems to be an additional factor regulating sex steroid binding protein (SBP) level which may alter the percentage of free testosterone available for negative feedback mechanism. The decrease of SBP, results in an increase of free androgen concentration in the serum. ${ }^{5}$ Street found that nonesterified fatty acids modify binding affinities of sex steroid hormones to SBP. ${ }^{6}$

The aim of the study is to elucidate the effects of the western diet (fat $35 \%$, protein $25 \%$, and carbohydrate $40 \%$ ) on sperm levels in cynomologus monkeys injected with TE plus DMPA.

\section{METHODS}

The cynomologus monkey ( Macaca fascicularis) used in this study were obtained from the Primate Center of Bogor Agriculture Institute and originated from Tinjil Island, West Jawa, Indonesia. Twenty adult males (body weight 4.40 to $5.20 \mathrm{~kg}$, and 5 to 9 years old) were housed individually in cages sized $23 \times 21 \times 12$ inches, at room temparature of $20^{\circ}-29^{\circ} \mathrm{C}$. The twenty male cynomologus monkeys was divided into two groups of 10 animals. Group I was fed with "monkey chow" (9\% fat, $13 \%$ protein and carbohydrate $78 \%$ of calorie), while Group II was fed with western diet (fat $35 \%$, protein $25 \%$ and carbohydrate $40 \%$ ).

This investigation was divided into three periods:

a. Adaptation period ( 3 months: -12 to the commencement of treatment/week 0$)$.

b. Treatment period ( 6 months: week 0 to week 24 ).

c. Recovery period (3,5 months: week 24 to week 39$)$. See Table 1.

Table 1. Chart showing the periods of adaptation (-12 to 0$)$, treatment ( 0 to 24$)$, and recovery (24 to 39$)$ weeks.

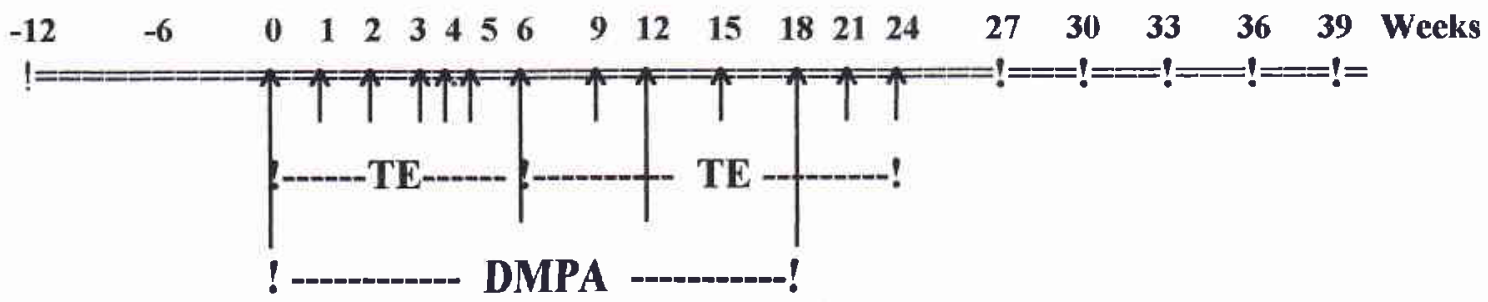

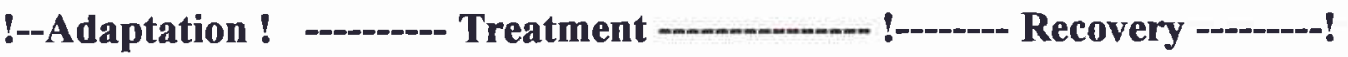


Three months after adaptation period, each group was injected with $20 \mathrm{mg}$ TE every week begining at week zero up to the week 6 and continued every 3 weeks there after until week 24 , combined with $25 \mathrm{mg}$ DMPA injection, starting at week zero and continued every 6 weeks up to the week 18 .

The semen collection using electro-ejaculation technique were carried out every three weeks, begining at week zero before adaptation period continued until the recovery period was terminated; sperm count and quality of sperm were determined by the WHO methods. ${ }^{7}$ The electro-ejaculator used in this study is shown in Figure 1.

Blood sample for the examination of FSH, LH, total testosterone (TT), free testosterone (FT), and estradiol (E2) levels using RIA technique were taken from femoral vein and performed at 6 week intervals.

Before the electroejaculation was performed all monkeys were anesthesized with ketamin-HCl. The semen was collected in gradual centrifuge tubes and the approximate volume was recorded. ${ }^{8}$ In this study the statistical analysis of SPSS "release-6 program" was used.

\section{RESULTS}

The results of parameters evaluated, are as follows:

\section{Sperm density}

Sperm count as well as sperm quality of all animals before and during adaptation period were normal, using WHO standard for human. The sperm density during: adaptation, treatment and recovery periods are depicted in Figure 2. Sperm density in the group I declined sharply 3 weeks after the first injection, all animals become azoospermic (100\%) at week 18, persisted up to week 30 or 6 weeks after TE injection withdrawal. In Group I, the sperm reappeared at very late stage of recovery period (week 33), and when this investigation terminated at week 39 the mean concentration of sperm reached the level of severe oligozoospermia only. More over two animals of this group remained azoospermic when this investigation terminated. On the other hand in group 2 only $70 \%$ af animals reached the azoospermic level in $24^{\text {th }}$ week (see Figure 3), and the lowest mean concentration of sperm was 1.42 million/ml at week 30 , after that the concentration increased to normozoospermia at the end of this study (week 39).

\section{Sperm quality}

The results of sperm quality evaluation i.e. the percentage of: sperm viability, sperm motility, sperm morphology, and sperm membrane integrity (HOS-test) are depicted in Figures: 4,5,6, and 7. In general it was found that the sperm quality parameters in Group I was lower than the Group II, reaching the lowest at 18th to 30th week (in accordance with azoospermic level of the Group I). In Group I the quality of sperm declined more rapidly compared to the Group II, the improvement of sperm quality in the Group I occured very slowly, while in the Group II the improvement of sperm quality occured faster.

\section{Serum Hormonal Concentration}

Serum hormone concentration of FSH, LH ( $\mathrm{mIU} / \mathrm{ml})$, total testosterone (TT) $(\mathrm{ng} / \mathrm{ml})$, free testosterone (FT) and estradiol (E2) (pg/ml), are depicted in Figures: 8, $9,10,11$ and 12 respectively. The concentrations of FSH and LH were decreased significantly in both groups (I and II) from week 6 through week 24. The FSH and LH levels were increased more rapidly in Group II compared to the Group I. The mean cocentration of serum TT showed no significant difference between groups, both groups showed increment at week 6, then decreased again at week 12 up to week 36. The mean serum FT was different between Groups, being higher in the Group I compared to the Group II. Thus, at week 6 FT in Group I was $83.54 \pm 7.17 \mathrm{pg} / \mathrm{ml}$ while in Group II was $30.29 \pm 9.18 \mathrm{pg} / \mathrm{ml}$. The difference continued from 6 th week to 24 th week (see also Figure 11). There was no difference concentration of estradiol in both groups; the cocentration increased to the highest level at week 6, but decreased again at week 12 and after.

\section{DISCUSSION}

This study has shown that the injection of TE in combination with DMPA induced azoospermia in 2 groups of cynomologus monkeys (Macaca fascicularis) fed with different diet formula; the Group I was fed with monkey chow diet (low fat and protein, high carbohydrate) while Group II was fed with western diet (high fat and protein, low carbohydrate). This phenomenon is very understandable, because exogenous testosterone (TE) and progestogene (DMPA) supressed the production of LH and FSH by hypophysis or indirectly supressed the production of LH-RH by hypothalamus. In both cases, finally the production of spermatozoa will be supressed. But 


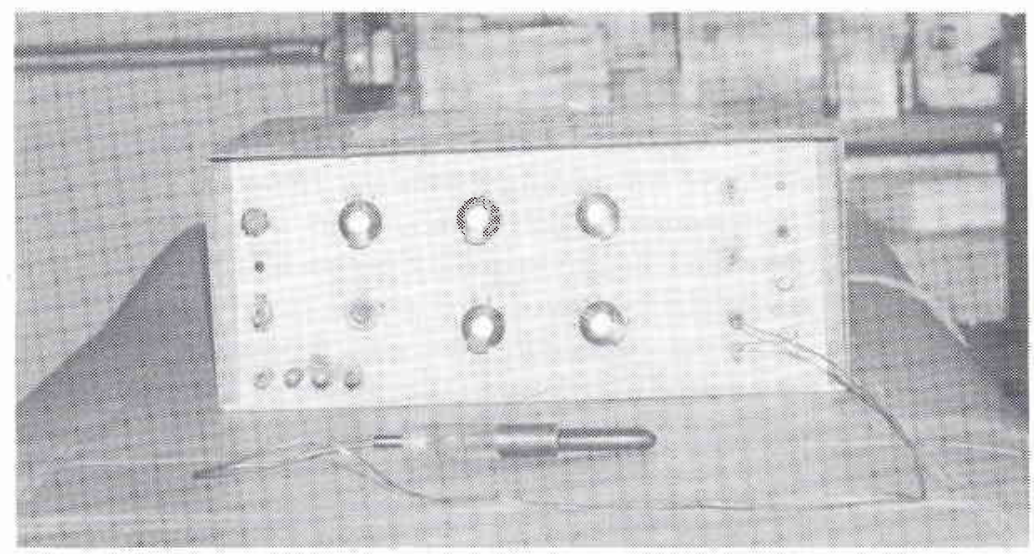

Figure 1. The electro-ejaculator used for semen collection, the body instrument (top) and rectal probe (bottom)

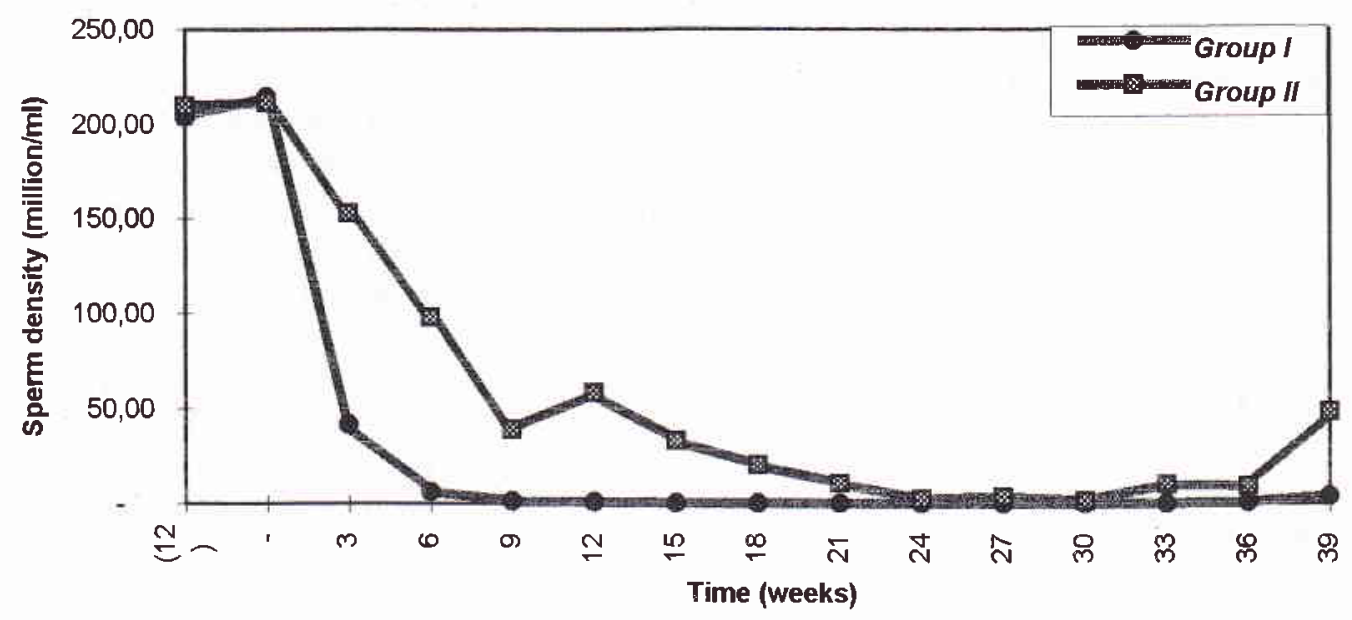

Figure 2. The sperm density of $M$. fascicularis injected with TE plus DMPA at different periods: adaptation ( -12 to 0 weeks); treatment (0 to 24 weeks); recovery ( 24 to 39 weeks).

Group I, monkey-chow diet; Group II, western diet.

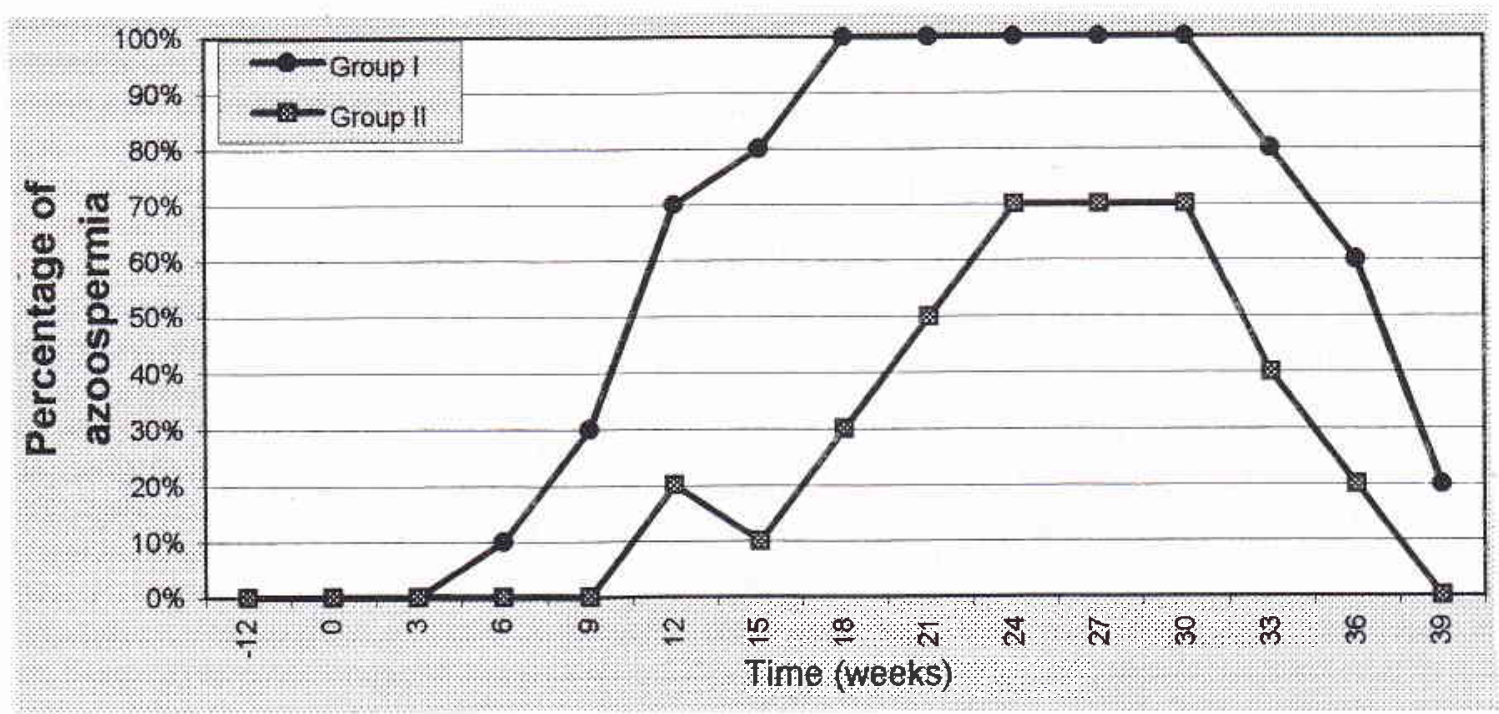

Figure 3. The percentage of azoospermic levels of M. fascicularis injected with TE plus DMPA at different periods: adaptation ( -12 to 0 weeks); treatment ( 0 to 24 weeks); recovery (24 to 39$)$.

Group I, monkey-chow diet; Group II, western diet. 


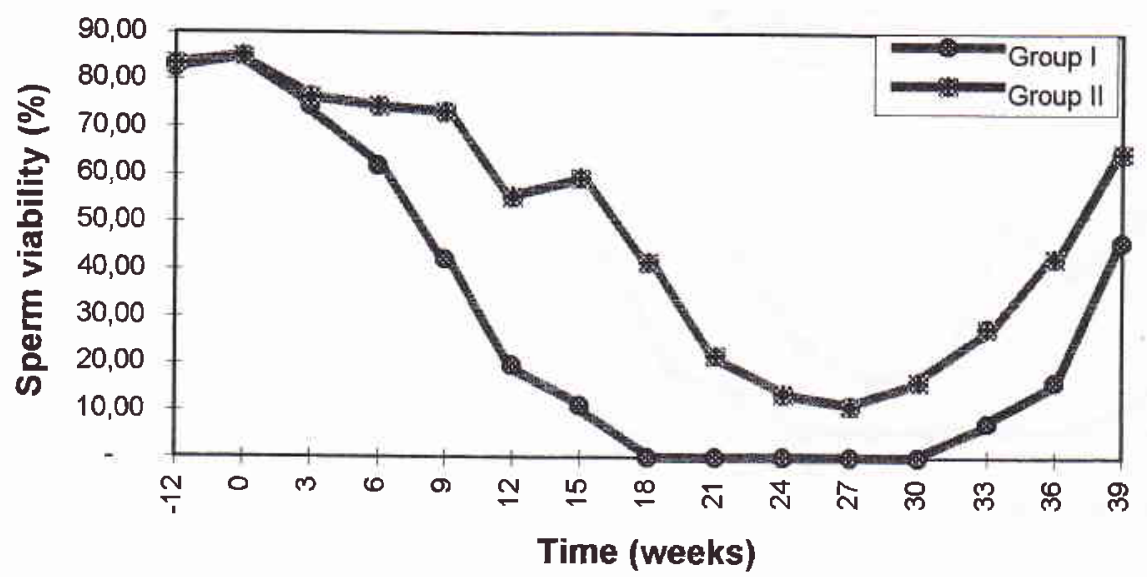

Figure 4. The sperm viability of M. fascicularis injected with TE plus DMPA at different periods: adaptation ( -12 to 0 weeks); treatment (0 to 24 weeks); recovery (24 to 39 weeks). Group I, monkey-chow diet; Group II, western diet.

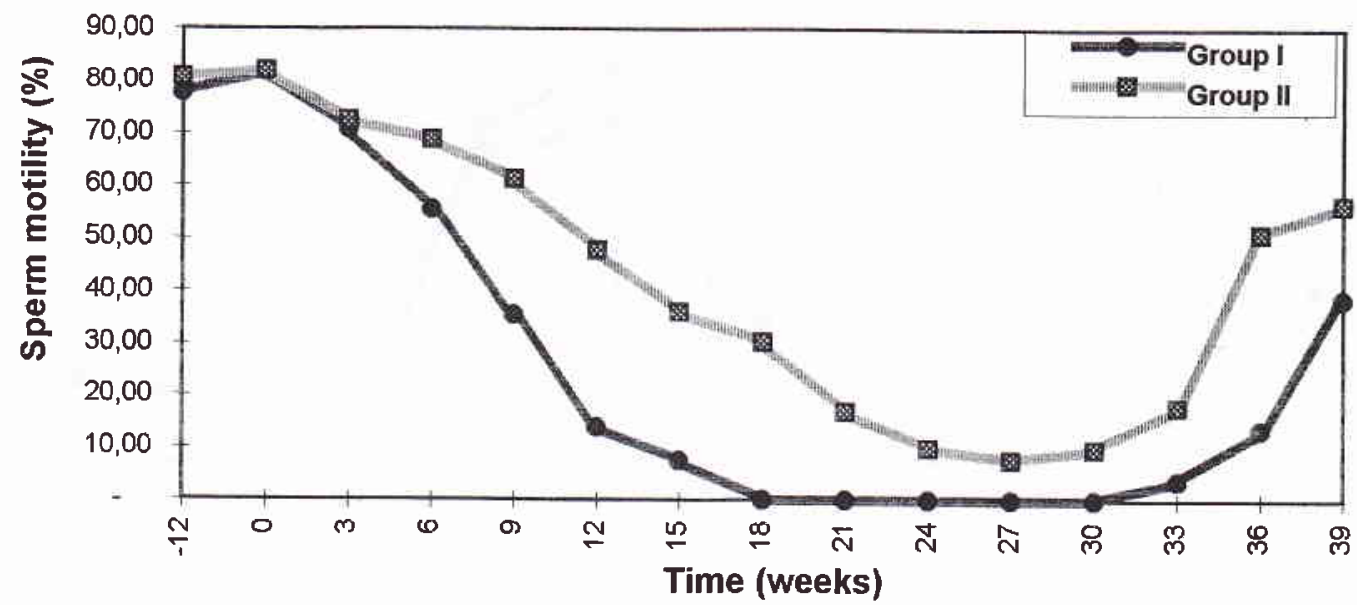

Figure 5. The sperm motility of M. fascicularis injected with TE plus DMPA at different periods: adaptation (-12 to 0 weeks); treatment ( 0 to 24 weeks); recovery (24 to 30 weeks).

Group I, monkey-chow diet; Group II, western diet.

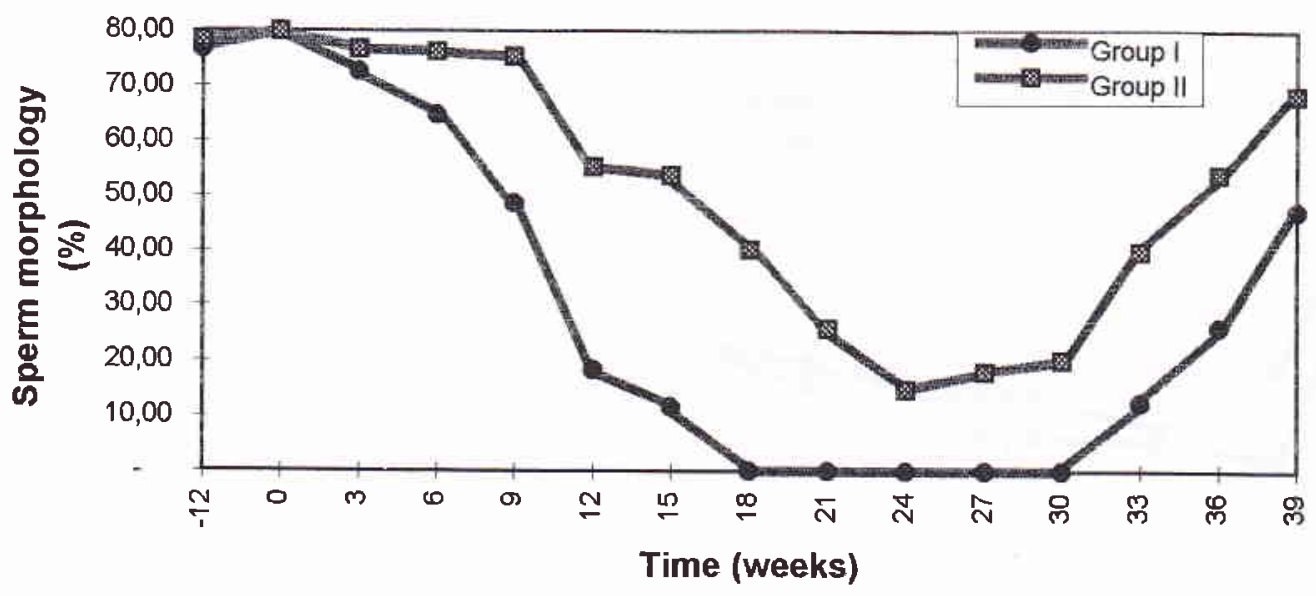

Figure 6. The sperm morphology of $M$. fascicularis injected with TE plus DMPA at different periods: adaptation ( -12 to 0 weeks); treatment (0 to 24 weeks); recovery (24 to 39 weeks).

Group I, monkey-chow diet; Group II, western diet. 


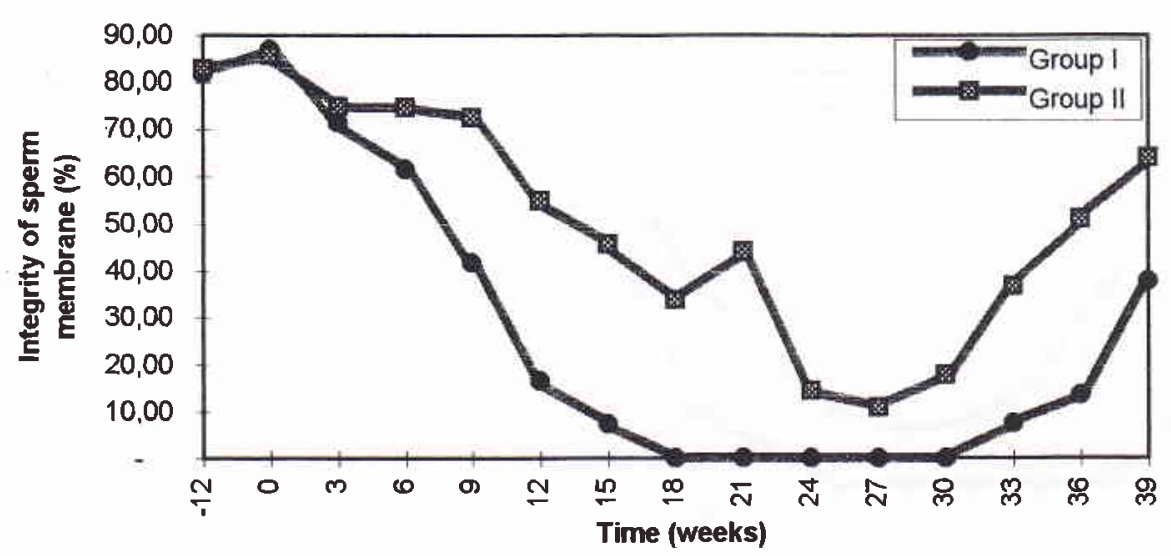

Figure 7. The integrity of sperm membrane of M. fascicularis injected with TE plus DMPA at different periods: adaptation ( -12 to 0 weeks); treatment ( 0 to 24 weeks); recovery (24 to 39 weeks). Group I, monkey-chow diet; Group II, western diet.

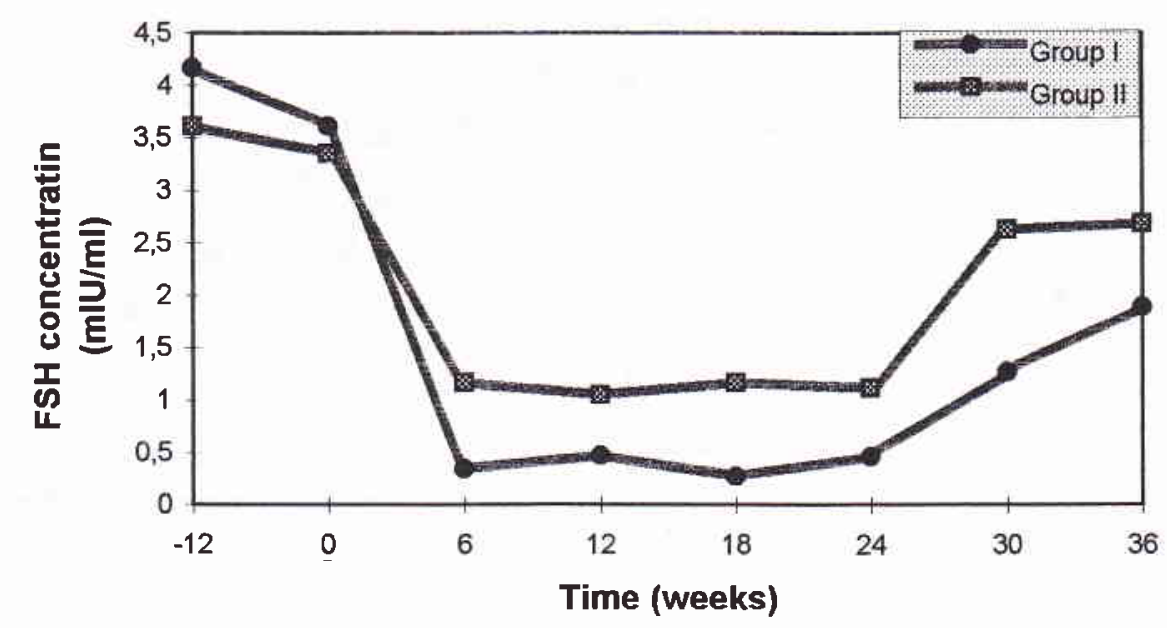

Figure 8. The FSH levels of M. fascicularis injected with TE plus DMPA at different periods: adaptation (-12 to 0 weeks); treatment ( 0 to 24 weeks); recovery (24 to 36 weeks). Group I, monkey-chow diet; Group II, western diet.

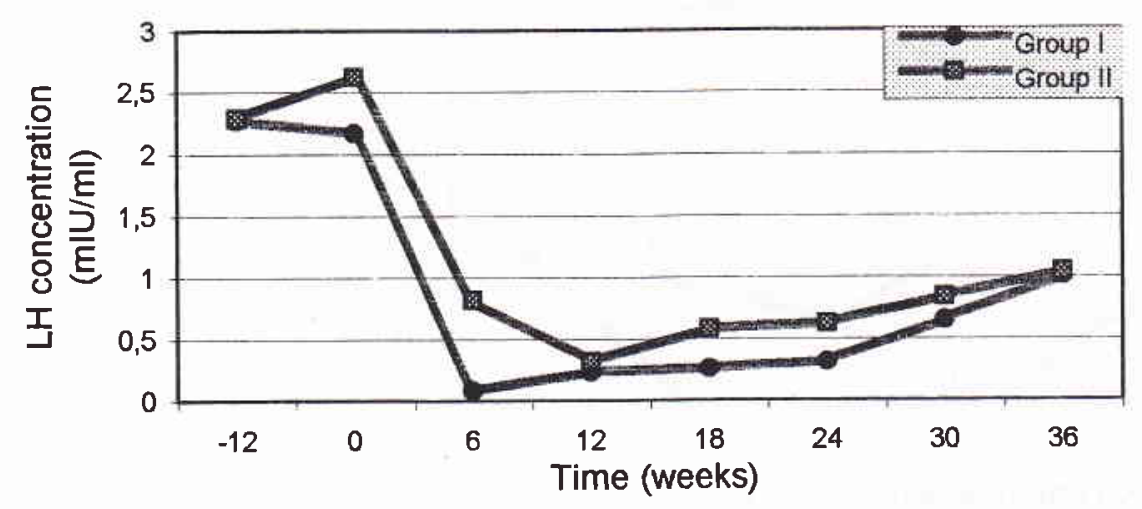

Figure 9. The LH levels of M. fascicularis injected with TE plus DMPA at different periods: adaptation ( -12 to 0 weeks); treatment ( 0 to 24 weeks); recovery (24 to 36 weeks). Group I, monkey-chow diet; Group II, western diet. 


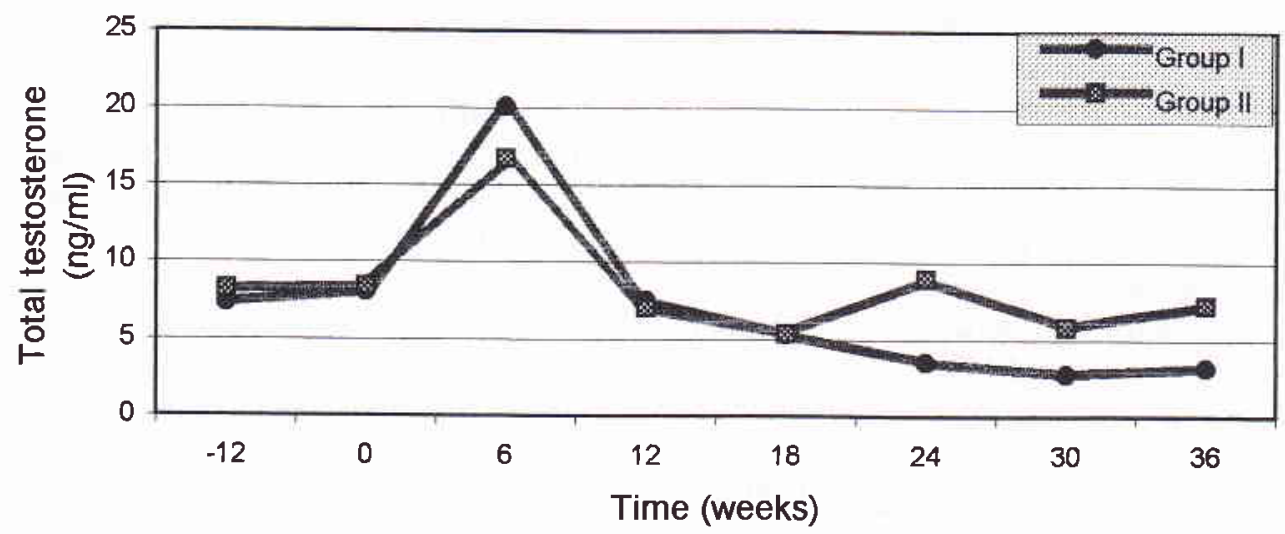

Figure 10. The total testosterone levels of $M$. fascicularis injected with TE plus DMPA at different periods: adaptation ( -12 to 0 weeks); treatment ( 0 to 24 weeks); recovery (24 to 36 weeks). Group I, monkey-chow diet; Group II, western diet.

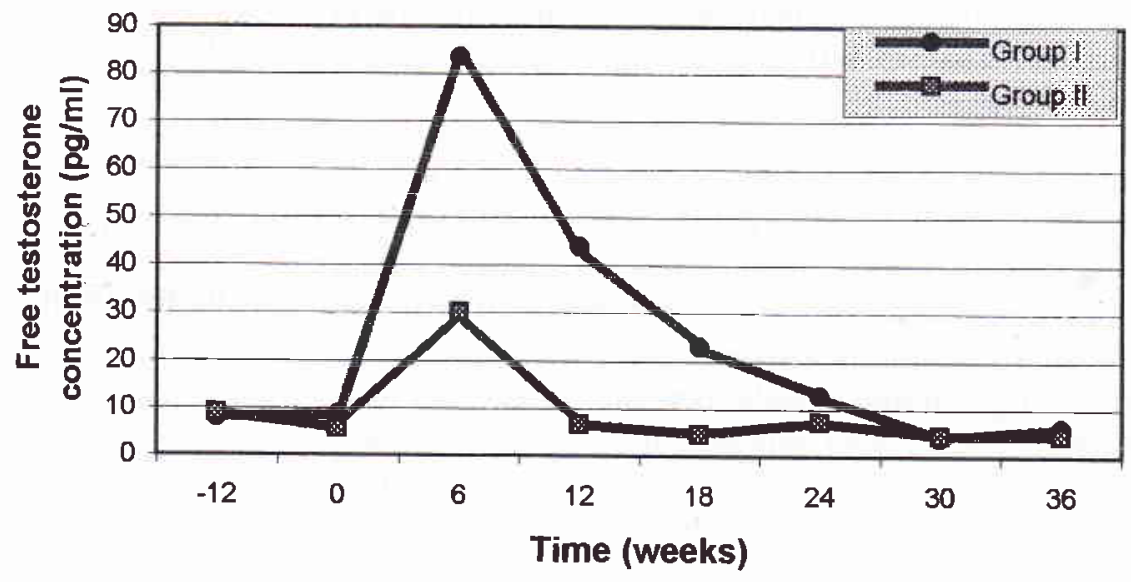

Figure 11. The free testosterone levels of $M$. fascicularis injected with TE plus DMPA at different periods: adaptation ( -12 to 0 weeks); treatment ( 0 to 24 weeks); recovery (24 to 36 weeks). Group I, monkey-chow diet; Group II, western diet.

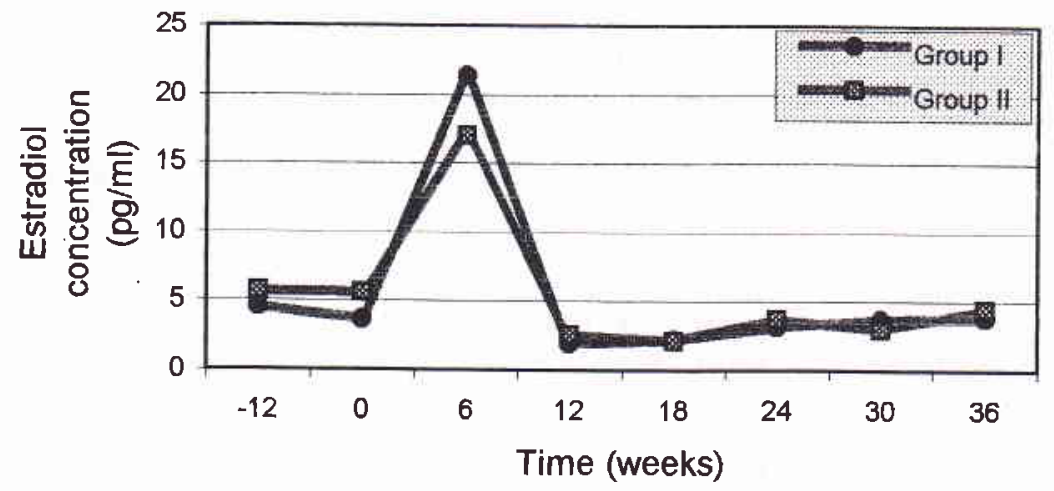

Figure 12. The estradiol levels of M. fascicularis injected with TE plus DMPA at different periods: adaptation (-12 to 0 weeks); treatment ( 0 to 24 weeks); recovery (24 to 36 weeks). Group I, monkey-chow diet; Group II, western diet. 
since there was a difference of the effectiveness of TE plus DMPA injection to induce azoospermic levels, i.e. highly effective in Group I (100\% azoospermic), while in Group II less effective ( $70 \%$ azoospermic), this phenomenon should be elaborated further. As a consequence of TE and DMPA injections it is natural that the FSH and LH levels drop simultaneusly (in this study 6 weeks after the first injection), and serum testosterone increases (see Figures: 8, 9, 10, and 11).

Total testosterone as well as free testosterone levels in both groups increased to the highest level 6 weeks after the first injection, but the concentration of free testosterone in Group I is much higher then the concentration of free testosterone in Group II. This situation explained why TE plus DMPA injection induced azoospermic levels in Group I more effectively than in Group II. This explanation also hold true for the difference of the sperm quality where in general the sperm quality of the Group II is better compared to the quality of the Group I.

Why free testosterone in Group I is higher then in Group II? This situation, may be related to the production of sex hormone binding globulin (SHBG). As has been mentioned earlier (see the Introduction), that nutritional status is also possible to be a factor influencing steroid metabolism that affects fertility. Lermite and Terqui reported that nutritional status seems to be an additional factor regulating sex steroid binding protein (SBP) level which may alter the percentage of free testosterone available for negative feedback mechanism. The decrease of SBP, results in an increase of free androgen concentration in the serum. ${ }^{5}$ Street found that nonesterified fatty acids modify binding affinities of steroid sex hormones to SBP. ${ }^{6}$

Several experimental studies have suggested that diet can alter the production and metabolism of steroid and SHBG in men. ${ }^{9}$ Reed et al. recently demonstrated that a low fat diet administered to normal men decreased the SHBG levels and increased the free-testosterone concentrations. ${ }^{10}$ These studies suggest that diet has an effect on steroid secretion or metabolism. In another study, western diet ( $40 \%$ of calories from fat) fed to vegetarian men increased the urinary excretions of estrogens and androgens while such excretion decreased when omnivorous men were fed with vegetarian diet. ${ }^{11,12}$ Thus, nutritional or diet status seems to be an additional factor regulating SHBG or SBP levels which may alter the percentage of free testosterone available for negative feedback, and excretion or metabolism of steroid hormones. Epidemiological studies showed that SHBG was positively correlated to total testosterone and negatively correlated to insulin hormone. ${ }^{13}$ Street found that nonesterified fatty acids modify binding affinities of sex steroid hormones to SBP. ${ }^{6}$

This studies showed that total testosterone was the sin the Group I was higher; so it is reasonable to believe that the level of SHBG was higher in Group II or may be the level of SHBG was the same but the binding affinities was lower in Group I, or may be the combination of two factors. This problems need further clarifications in another studies.

\section{CONCLUSION}

This investigation concluded that different diet formula caused different results in decreasing the level of sperm quantity and quality, and hormone concentration of M. fascicularis injected with TE in combination with DMPA, being lower in animals fed with the monkey chow diet than in animals fed with the western diet.

\section{REFERENCES}

1. Pangkahila W. Reversible azoospermia induced by an androgen-progestin combination regimen in Indonesian men. Int J Androl 1991; 14: 248-56.

2. Moeloek N. Comparison of two androgens plus depotmedroxyprogesterone acetate for suppression to azoospermia in Indonesian men. Fertil Steril 1993; 60: 1062-8.

3. Gui-yuan Z. Contraceptive efficacy of testosterone induced azoospermia in normal men. The Lancet 1990; 336: 955-9.

4. Arsyad KM. Progestogen-Androgen combination: Results of Indonesian clinical trials. Med J Indon 1997; 6: 15-24.

5. Lermite V, Terqui M. Plasma sex steroid binding protein in mature heifers: Effect of the reproductive status, nutritional levels, and porcine growth hormone and estradiol treatment. Biol Reprod 1991; 44: 864-70.

6. Street C, Herry RJS, Al-Othman S, Chard T. Inhibition of binding of gonadal steroid to serum binding protein by non-esterified fatty acids: The influence of chain length and degree of unsaturation. Acta Endocrinol 1989; 120: 175-9.

7. World Health Organization (WHO). Penuntun laboratorium untuk pemeriksaan semen manusia dan interaksi semen getah servik. Translations by Tadjudin MK, Balai Penerbit FKUI Jakarta 1990.

8. Lipshultz LI, Witt MA, Grantmyre JE. Electroejaculation. Infertil Reprod Med Clin 1992; 3:455-66.

9. Belanger A, Locong A, Noel C, et al. influence of diet on plasma steroid and sex plasma binding globulin levels in adult men. J Steroid Biochem 1989; 32: 829-33.

10. Reed MJ, Cheng RW, Simmonds M, Richmond W, James VHT. Dietary lipid: an additional regulator of plasma levels of SHBG. J Clin Endocrin Metab 1987; 64: 1083-5. 
11. Hill P, Wynder EL, Garbaczewski L, Walker ARP. Effects of diet on plasma and urinary hormones in South African Black Men with prostastic cancer. Cancer Res 1982; 42: 3864-9.

12. Gates JR, Parpia B, Campbell TC, Junshi C. Association of dietary factors and selected plasma variables with SHBG in rural Chinese women. Am J Clin Nutr 1996; 63: 22-31.
13. Hautanen A, Sarna S, Pelkonen R, Adlercreutz H. Serum sex-hormone binding globulin (SHBG), cardiovascular risk factors, and adrenal cortisol responses to dexametasone and corticotropin. Metabolism 1993; 42: 870-4. 